\title{
IfISGUC.ORG
}

"iş, GÜÇ" ENDÜSTRi iLişKILERI VE INSAN KAYNAKLARI DERGiSi

"IS, GUC" INDUSTRIAL RELATIONS AND HUMAN RESOURCES JOURNAL

\section{Makyavelizm'in Olumsuz Durumları İfşa Etme Niyeti Üzerindeki Etkisi: Bir Alan Çalışması}

\author{
Özgür DEMİRTAŞ \\ Dr.Y.Müh., Türk Hava Kuvvetleri Komutanlığ1
}

D. Mehmet BİÇKES

Yrd.Doç.Dr., Nevşehir Üniversitesi

Nisan/April 2014, Cilt/Vol: 16, Say1/Num: 2, Page: $98-112$

ISSN: 1303-2860, DOI: 10.4026/1303-2860.2014.0249.x

Makalenin on-line kopyasına erişmek için / To reach the on-line copy of article:

http://www.isguc.org/?p=article\&id=547\&cilt=16\&sayi $=2 \& y i l=2014$

Makale İçin İletişim/Correspondence to:

Dr.Özgür DEMIRTAŞ, , email: ozgurdemirtas@hvkk.tsk.tr 


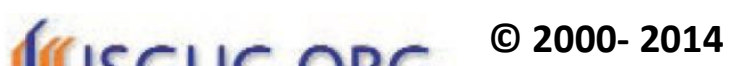 \\ "İ̧̧,Güç" Endüstri iliş̧kileri ve İnsan Kaynakları Dergisi "İş, Güç" Industrial Relations and Human Resources Journal
}

\author{
Nisan/April 2014, Cilt/Vol: 16, Say1/Num: 2, Page: 98-112 \\ ISSN: 1303-2860, DOI: 10.4026/1303-2860.2014.0249.x
}

"Işs,Güç" Endüstri İlişkileri ve İnsan Kaynakları Dergisi, yılda dört kez yayınlanan hakemli, bilimsel elektronik dergidir. Çalışma hayatına ilişkin makalelere yer verilen derginin temel amacl; belirlenen alanda akademik gelişime ve paylaşıma katkıda bulunmaktır.

"İş, Güç" Endüstri İlişkileri ve İnsan Kaynakları Dergisi'nde, 'Türkçe' ve 'İngilizce' olarak iki dilde makale yayınlanmaktadır. "İş,Güç" Endüstri İlişkileri ve İnsan Kaynakları Dergisi, ulusal ve uluslararası birçok indekste taranmaktadır. (Cabell's Directories, Ebsco Socindex, Index Islamicus, Index Copernicus International, Worldwide Political Science Abstracts, Sociological Abstract, Ulakbim Sosyal Bilimler Veritabanı, ASOS Index)

Editörler Kurulu / Editorial Board Aşkın Keser (Uludă̆ University) K.Ahmet Sevimli (Uludă̆ University) Şenol Baştürk (Uludağ University)

\section{Editör / Editor in Chief}

Şenol Baştürk (Uludăg University)

\section{Uygulama / Design}

Yusuf Budak (Kocaeli University)

\section{Tarandı̆̆ı Indeksler / Indexes} ASOS INDEX

CABELL'S DIRECTORIES EBSCO SOCINDEX Index ISLAMICUS Index COPERNICUS Int. Sociological Abstract ULAKBİM Sosyal Bilimler Veritanı

Worldwide Political Science Abstracts

\author{
Yayın Kurulu / Editorial Board \\ Yrd.Dr.Şenol Baştürk (Uludă̆ University) \\ Yrd.Doç.Dr.Zerrin Fırat (Uludă̆ University) \\ Prof.Dr.Aşkın Keser (Uludağ University) \\ Prof.Dr.Ahmet Selamoğlu (Kocaeli University) \\ Yrd.Doç.Dr.Ahmet Sevimli (Uludağ University) \\ Doç.Dr.Abdulkadir Şenkal (Kocaeli University) \\ Doç.Dr.Gözde Yılmaz (Marmara University) \\ Yrd.Doç.Dr.Memet Zencirkıran (Uludă̆ University)
}

Uluslararası Danışma Kurulu / International Advisory Board

Prof.Dr.Ronald Burke (York University - Kanada)

Assoc.Prof.Dr.Glenn Dawes (James Cook University - Avustralya)

Prof.Dr.Jan Dul (Erasmus University - Hollanda)

Prof.Dr.Alev Efendioğlu (University of San Francisco - ABD)

Prof.Dr.Adrian Furnham (University College London - Ingiltere)

Prof.Dr.Alan Geare (University of Otago - Yeni Zellanda)

Assoc. Prof. Dr. Diana Lipinskiene (Kaunos University - Litvanya)

Prof.Dr.George Manning (Northern Kentucky University - ABD)

Prof.Dr.Mustafa Özbilgin (Brunel University - UK)

Assoc. Prof. Owen Stanley (James Cook University - Avustralya)

Prof.Dr.Işık Urla Zeytinoğlu (McMaster University - Kanada)

Ulusal Danışma Kurulu / National Advisory Board

Prof.Dr.Yusuf Alper (Uludă̆ University)

Prof.Dr.Veysel Bozkurt (Ístanbul University)

Prof.Dr.Toker Dereli (Işık University)

Prof.Dr.Nihat Erdoğmuş (İstanbul Şehir University)

Prof.Dr.Ahmet Makal (Ankara University)

Prof.Dr.Süleyman Özdemir (İstanbul University)

Prof.Dr.Ahmet Selamoğlu (Kocaeli University)

Prof.Dr.Nadir Suğur (Anadolu University)

Prof.Dr.Nursel Telman (Maltepe University)

Prof.Dr.Cavide Uyargil (Istanbul University)

Prof.Dr.Engin Yildırım (Anayasa Mahkemesi)

Doç.Dr.Arzu Wasti (Sabancı University)

Dergide yayınlanan yazılardaki görüşler ve bu konudaki sorumluluk yazarlarına aittir.

Yayınlanan eserlerde yer alan tüm içerik kaynak gösterilmeden kullanılamaz.

All the opinions written in articles are under responsibilities of the authors.

The published contents in the articles cannot be used without being cited. 


\title{
Makyavelizm'in Olumsuz Durumları İfşa Etme Niyeti Üzerindeki Etkisi: Bir Alan Çalışması
}

\section{The Effects of Machiavellianism on Whistleblowing: A Field Study}

\author{
Özgür DEMIRTAŞ \\ Dr.Y.Müh., Türk Hava Kuvvetleri Komutanlığı \\ D. Mehmet BİÇKES \\ Yrd.Doç.Dr., Nevşehir Üniversitesi
}

\section{Özet}

Makyavelizm konusunda literatürde çok sayıda çalışma yapılmış ve kavramın organizasyonlar açısından önemi birçok etik araştırmasında vurgulanmıştır. Ancak, yapılan incelemeler sonucunda literatürde makyavelizm ve olumsuz durumlarl ifşa etme (whistleblowing) ilişkisine yönelik yeterli düzeyde çalışma olmadığı gözlenmiştir. Bu çalışma kapsamında, makyavelizm kavramını olumsuz durumları ifşa etme mekanizması çerçevesinde daha derinlemesine anlamak amacıyla, makyavelizmin olumsuz durumları ifş̧a etme niyeti üzerindeki etkisi araşttrılmıştır. Bu amaca yönelik yapılan analizlerde, kurulan hipotez çerçevesinde makyavelizmin birinci ve üçüncü kişi olumsuz durum if̧sa niyetini negatif yönde etkilediği tespit edilmiştir. Çalışma bulgularının, özellikle Türk literatürü açısından henüz yeterli düzeyde araştırmanın yapılmadığı makyavelizm ve olumsuz durumların ifşa edilmesi alanına önemli katkılar sağlayacağı umulmaktadır.

Anahtar kelimeler: Örgüt, Etik, Makyavelizm, Olumsuz Durumları Ifş̧a Etme.

\begin{abstract}
There are a lot of studies in the literature that mentioned Machiavellianism. This construct and its importance are given in a wide range of ethics research. But, there are few studies mentioning the relationship between Machiavellianism and whistleblowing. So, in this study we examine the effect of Machiavellianism on whistleblowing intention. Results support our hypothesis that Machiavellianism has negative effect on the first and third person whistleblowing intention. These findings contribute to the Turkish literature in that there are very few studies on how Machiavellianism and whistle-blower intention are related.
\end{abstract}

Keywords: Organization, Ethics, Machiavellianism, Whistleblowing, 


\section{Giriş}

Son y1llarda yaşanan etik skandallarla (örn. Enron, Tyco, WorlCom) önemi daha da çok ortaya çıkan etik kavramı, işletmeler açısından da daha merkezi bir konuma gelmeye başlamıştır (Seifert ve diğ., 2010: 711). Özellikle, kurumsallaşmış veya bu yolda ilerleyen firmaların paydaşlarına karşı olan sorumlulukları gereği etik bakış açısını ve bu yönde teşvik edici davranışları desteklediği gözlenmektedir. Bu yönde de sosyal olarak sorumlu eylemleri destekleyici kurumsal mekanizmalar ortaya çıartılmaya başlanmıştır (Mesmer-Magnus ve Viswesvaran, 2005: 283). Çünkü günümüz organizasyonları artık, kurumlarına ve paydaşlarına zarar verebilecek ahlaki olmayan, yasa dişı ve illegal olaylara karşı daha da duyarlı hale gelmektedir. $\mathrm{Bu}$ noktada örgütlerde ahlaki olmayan bu tür davranışları örgüte zararı dokunmadan erken aşamalarda bildiren whistleblower'lar yani olumsuz durumları ifşa edenler büyük ölçekli kurumsal zararların da önüne geçilmesinde önemli oranda katkı sağlamaktadırlar (Tavakoli ve diğ., 2003: 58). Bu nedenle, olumsuz durumları ifşa etme mekanizmasıyla ilgili faktörlerin daha iyi anlaşılması ve bu çerçevede çeşitli organizasyonel düzeylerde ilave faydalar sağlanacağı düşüncesiyle, literatürde bu yönde yapılacak araştırmaların önemli araştırmalar arasında olduğu ifade edilmektedir (Seifert ve diğ., 2010: 711).

Olumsuz durumları ifşa etme mekanizmasına geleneksel yönetim düşünürleri şiddetle karş1 çıkmakta ve sorunu bildirenleri sadakatsizliklerinden dolayı cezalandırılmayı hak eden sorunlu kişiler olarak görmekteyken, modern yönetim düşünürleri diğer regülasyon ve denetim biçimleri başarısız olursa, sorun bildirenleri çok değerli ve iş güvenliği açısından kendilerini feda eden bireyler olarak görmekte (Lewis ve Uys, 2007: 87) ve organizasyonel çıktılara katkıları nedeniyle o kişilere ayrı bir önem vermektedirler. Ülkemizin sahip olduğu kültürel yapı gereği ispiyonculuk, muhbirlik gibi negatif kavramlar olarak algilanabilen bu kavramin, aslinda organizasyonların sahip olduğu etik karakteristiklerin geliştirilmesi ve yanlış veya yasa dışı uygulamaların önüne geçilerek hakim bir etik iklim oluşturulması açısından önemli bir pro-sosyal davranış olduğunu ifade etmek mümkündür.

Organizasyonlarda olumsuz durumları ifşa etme niyetini etkileyen faktörlerden biri de Makyavelizm'dir. Çünkü, Makyavelist kişilerin daha çok bireysel çıkarlarını düşündükleri ve amaçlarına ulaşırken çeşitli seviyelerde manipülatif davranışlar sergiledikleri gözlenmektedir. İlave olarak, yüksek makyavelist duygusu içerisinde olanların ahlaki durumlarda etik normları terk ettikleri ve daha az etik davranışlar sergiledikleri ifade edilmektedir (O'Fallon ve Butterfield, 2005: 377). Bu nedenle, çalışmada bireyin Makyavelizm seviyesinin olumsuz durumları ifşa etme niyeti üzerinde önemli bir rol oynayacağı düşünülmektedir.

$\mathrm{Bu}$ çalışmada iki ana sebepten dolayı Makyavelizm konusu olumsuz durumları ifşa etme kavramı çerçevesinde araştırılmıştır. Birinci olarak, önceki çalışmalar (özellikle de Türkçe literatür) var olan teoriler çerçevesinde Makyavelizm ve olumsuz durumları ifşa etme niyeti arasındaki ilişkiyi yeterince araştırmamıştır. Bu nedenle organizasyonlar için ahlaki davranışların artırılması ve çalışanlarda bu yönde algıların oluşturulması adına önemli kazanımlar sağlayacak bu konunun incelenmesinin hem literatüre hem de uygulayıcılara önemli kazanımlar sağlayacağı değerlendirilmektedir. İkinci olarak, ilgili literatürde Makyavelist yapıda olan kişilerin olumsuz durumları ifşa etme niyetlerini artırma ve bu yönde teşvik edici uygulamalar geliştirmeleri yönünde bilgiler yeterli düzeyde verilmemiştir. Çalışmalarda, genelikle etik eğitimleri ile etik davranışların artırılacağı vurgulanmaktadır (Jukiewicz ve diğ., 2004: 291; Gautschi ve Jones, 1998: 212). Ancak, diğer bazı çalışmalarda ise etik eğitimlerinin yüksek makyavelist düzeyde olan kişilerin organizasyonlara zarar verici davranışlarını artırdığı yönde bulgular mevcuttur (Bloodgood ve diğ., 2010: 23). Bu 
nedenle mevcut çalışmanın kapsamı, organizasyonlarda rastlanan makyavelist davranışları ve olumsuz durumları ifşa etme mekanizmasını daha iyi anlayarak, makyavelizmin olumsuz durumları ifşa etme niyeti üzerindeki etkisini ortaya çıarmaktır.

Çalışmada öncelikle belirtilen amaca yönelik literatür incelenmiş ve ilgili literatür ışığında çalışmanın hipotezi oluşturulmuştur. Metodoloji bölümünde, çalışmanın örneklemi ve yöntemi verilerek elde edilen sonuçlar sunulmuştur. Son bölümde ise çalışmanın sonuçlarının özeti, çalışmanın kısıtları, üstünlükleri ve zayıflıkları verilerek, gelecek çalışmalar için çeşitli önerilerde bulunulmuştur.

\section{Literatür İncelemesi}

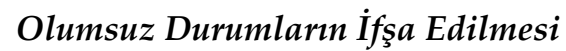

Olumsuz durumları ifşa etme (whistleblowing) kavramı ilk olarak güvenlik uygulamaları kapsamında ortaya çıkmış olup, tehlike ve risklerin yer aldığ 1 hukuki bir belgede kullanılmıştır. Türkçe'ye adaptasyonunda 1slık çalma gibi bir anlam taşısa da, gerçek anlamıla örgütsel alanda bir terim olarak etik değerlere ve yasalara aykırı davranışta bulunanların, bir düdük vasıtasıyla durdurulmaya çalışılması, bu kavramın özünü açiklamaktadır (Hersh, 2002: 245). Bu terim aslında İngiliz bir polisin suç işleme eğiliminde olan birisine, onu uyarmak amaciyla islik çalmasından kaynaklanmaktadır. $\mathrm{Bu}$ mekanizma, organizasyonlarda ahlaki olmayan, yasalara aykırı ve organizasyonel açıdan zararlı sonuçlar doğuracak nitelikteki uygulamaların düzeltilmesini sağlamak için ilgili organizasyondan ayrılmış birisi veya mevcut bir üye tarafından durumun kontrol altına alınması için, yetkili otoritelerin bilgilendirilmesi sürecini ifade etmektedir (Jubb, 1999: 3). Bazı kullanımlarda örgütsel alanda yaşanan muhalefetin de özel bir biçimi olarak ifade edilen olumsuz durumları ifşa etme mekanizması ikiye ayrılmaktadır. Bunlardan ilki olan içsel olumsuz durumları ifşa etme, kanuna ve ahlaka aykırı uygulamalar ve yolsuzluklar hakkında ilgili organizasyon üyelerini bilgilendirmeyi, dışsal olumsuz durumları ifşa etme olarak adlandırılan ikincisi ise, örgütsel yanlışlıklar ve yolsuzluklar kapsamında bir örgüt üyesinin işletme dışındaki grupları bilgilendirmesini ve harekete geçirmesini ifade etmektedir (Jubb, 1999: 3-10).

Olumsuz durumları ifşa etme mekanizmasının ana fikri, ahlaki standartları korumak, savurgan, zararlı ve yasal olmayan eylemlere engel olmak için işletmelerin ve çalışanların kötü eylemlerini teşhir etmektir (Berkman ve Arslan, 2009: 78; Liyanarachchi ve Newdick, 2009: 39; Nam ve Lemak, 2007: 40-42). Çünkü bu sistemde bireysel çıkarlar elde etmek için sergilenen makyavelist nitelikte davranışlar söz konusu değildir (Ateş ve diğg., 2009: 94). Chiu'ya (2002) göre olumsuz durumları ifşa etme mekanizması, bir örgütte yasalara aykırı, şüpheli veya ahlaka aykırı uygulamaların örgütteki mevcut ya da eski bir üye tarafından önlem alabilecek güç ve kaynaklara sahip kişi veya taraflara iletilerek açığa çıkarılması sürecini ifade etmektedir. Pro-sosyal davranış tipleri arasında gösterilen olumsuz durumları ifşa etme mekanizması, hem negatif bir sapkın işyeri davranışı olarak algılanmakta, hem de pozitif bir davranış olarak karakterize edilebilmektedir (Appelbaum ve diğ., 2007: 588). Bu nedenle olumsuz durumları ifşa etme mekanizması birçok yönüyle örgütsel yanlışlara karşı geliştirilen fakat çok yaygın olmayan bir tepki olarak nitelendirilmektedir (Blenkinsopp ve Edwards, 2008: 184). Kapalı kültüre sahip bazı toplumlarda negatif bir kavram olarak algilanan (Bennett ve Stamper, 2001: 274) bu sistemde, sorunu ifşa edenler genelde işini kaybetme, ücret azalması, toplumdan dişlanma, ayrımcilığa maruz kalma, arkadaşlık ilişkilerinin bozulması vs. sorunlarla karşı karşıya kalmaktadırlar (Biegelman ve Bartow, 2006: 254-255; Bucka ve Kleiner, 2001: 51).

İşletmelerde ahlaki olmayan veya yasa dişı uygulamaların ortaya çıkmasını engelleyen bazı önemli faktörler mevcuttur (Özgener ve diğ., 2012: 8; Nam ve Lemak, 2007: 38; Schermerhorn, 1989: 610). Bunlardan ilki bireyin ahlaki değgerleri olup, bu değer sistemi bir organizasyonda çalışan bir işgörenin ahlaki değer yargılarına göre, olumsuz durumları ifşa 
etme alanı olarak ifade edilen sorun bildirme alanı olduğunu işaret etmektedir. Bu alan direkt olarak bireysel değerlerle bağlantılıdır ve bu değerler birey bir konuda karar verirken onun hangi kuralı izleyebileceğini ve nasıl iletişimde bulunacağını etkilemektedir. İkincisi informal örgüt yapısıdır. Bu tür bir örgüt, kendiliğinden oluşan ve biçimsel örgüt şekilleriyle temsil edilmeyen, fakat özünde biçimsel örgütün bir parçası olan kişilerin bağlantıları, etkileşimleri ve ilişkili oldukları insanları ihtiva eden grupları ifade etmektedir. Olumsuz durumları ifşa etme mekanizmasında alternatif iletişim kanallarından bu tür informal yapılar çok önemli bir işlev görmektedir. Üçüncüsü liderin otoritesidir. Örgütsel çatışmaların yönetiminde yönetici pozisyonunda görev alanlar önemli bir rol oynamaktadır. Ahlaki çatışmaların yaşandığı durumlardaki karmaşıklığı çözme becerisi yöneticiye bir moderator rolü yüklemektedir. Birçok vakada gözlemlendiği üzere astlar, bulundukları pozisyondan dolayı değil, liderin kişisel yeteneğine sayg1 gösterdiklerinden dolayı onun emirlerini kabul etmektedir. Örneğin Enron vakasında Sherron Watkins tespit ettiği problemlere ilişkin tepkisini önce doğrudan CEO Kenneth Lay'e iletmiş ve bu durum soruna kısa sürede çözüm bulmasına engel olmuştur. Dördüncü olarak katı emir-komuta zinciri ifade edilmektedir. Katı bir emir-komuta zinciri üst düzeydeki bir yöneticinin ahlaki olmayan veya yasalara aykırı davranışlarını raporlamayı güçleştirmektedir. Hatta bazı durumlarda, emir komuta zincirindeki yöneticiler, astlarının kötü eylemlerinin açığa çıkarılmasıyla ilgili önlemleri almayı dahi reddedebilmektedir. Son faktör görev-grup bağglllığ $ı$ şeklinde ifade edilmektedir. Bu faktör grup normlarının, üyelerin davranışları üzerinde çok güçlü etkilere sahip olduğunu vurgulamaktadır. Hatta, bazı durumlarda grup normları üyelerin ahlak standartlarını ihlal eden davranışları dahi desteleyebilmektedir. Grup normlarını ihlal etmek, sosyal ilişkiyi kesme ve hatta grup üyeliği imtiyazlarını kaybetmeyle sonuçlanabilmektedir. Bu nedenle, işgörenler sorun bildirme mekanizmasinı harekete geçirmeye çalışmak yerine grup üyeleriyle beraber hareket etme eğiliminde olabilmektedir.

Olumsuz durumları ifşa etme, hem hileyi tespit eden, hem de önleyen nadir kurumsal mekanizmalardan biridir (Biegelman ve Bartow, 2006: 254-255). Sorun bildirme mekanizmasından elde edilen yararlar arttıkça toplumda bu prosedürü kabullenme ve konuya daha da çok önem verme eğilimi ortaya çıkmıştır. Örneğin; 2002 yılında ABD'de çeşitli yolsuzlukların ortaya çıkarılmasında çok önemli roller üstlenen üç kadın çalışan (Cynthia Cooper-WorldCom, Coleen RowleyFBI ve Sherron Watkins-Enron) Time Dergisi'nin kapağında "Persons of the Year 2002 (2002 Yılının Çalışanları)” başlığı ile yer almıştır (Lacayo ve Ripley, 2002: 5).

Literatürde olumsuz durumları ifşa etme mekanizmasına yönelik çeşitli çalışmalar yer almaktadır. Örneğin, Mesme-Magnus ve Viswesvaran (2005) yaş ve işyeri pozisyonu ile; Sims ve Keenan (1998) cinsiyet ile; Tavakoli ve diğerleri (2003) ve Park ve diğerleri (2005) kültür ile; MacNab ve Worthley (2008) özyeterlilik ile; Taylor ve Curtis (2010) ahlaki yoğunluk ile; Robinson ve diğerleri (2012) ise yanlış davranış özellikleri ile olumsuz durumları ifşa etme arasındaki ilişkileri incelemişlerdir. $\mathrm{Bu}$ çalışmada ise olumsuz durumları ifşa etme mekanizmasına farklı bir perspektiften yaklaşılarak makyavelizm ile olan ilişkisi ele alınmıştır.

\section{Makyavelizm}

Makyavelizm, İtalyan politikacı Niccolo Machiavelli'nin "De Principatibus - Prenslikler Hakkında" adlı kitabında yer alan düşünceler üzerine kurulu bir yaklaşımdır. Machiavelli, kitabında temel olarak "amaca ulaşmak için her yolun mübah olduğu" savını dile getirmiştir. Benzer şekilde Teven (2007: 342), Niccolo Machiavelli'nin (1469-1527) "The Prince and The Discourses" (1513/1966) başlığ altında toplanan yazı ve düşünceleri ile temelleri atılan makyavelizmin, Christie ve Geis (1970)'in çalışmalarıyla yeni ufuklar kazandığını dile getirmektedir.

Makyavelizm kavramı O'Connor ve Athota (2013: 750) tarafından, bireysel çıkarları her 
şeyin üzerinde tutma, amaçlara ulaşmak için diğerlerini kullanma ve sömürme ve duygusal manipülatif davranışlarla karakterize edilen bir kişilik özelliği olarak tanımlanmıştır. Robbins (1998: 58) ise kavramı, bireylerin pragmatik olma, duygusal mesafe koyabilme ve elde edilecek sonuçların yolları mubah kıldığına inanma derecesi olarak tanımlamıştır. Sinik, şüpheci, baskıcl, soğuk, ahlaki değerlerden yoksun, anti-sosyal eğilimli kişiler olan makyavelist bireyler (Ali ve diğ., 2009: 758), uzun vadeli stratejik planlama yapabilen ve kişilerarası sosyal rekabette güç kazanma odaklıdırlar (Rauthmann, 2012: 345; Kareshki, 2011: 415). Paal ve Bereczkei (2007: 543), makyavelist bireylerin temel özelliklerini diğer bireylere yönelik negatif niyet ve işbirliğinden uzak olma şeklinde sıralamış ve bunun gerisindeki temel düşünceninde diğerlerini kullanmayı beceremeyen bireylerin diğerleri tarafından kullanılacağı varsayımı olduğunu belirtmiştir.

$\mathrm{Bu}$ açıklamalar çerçevesinde makyavelist bireylerin, amaca yönelik rekabetçi stratejiler oluşturmada son derece başarılı oldukları söylenebilir. Bu anlamda Güney ve Mandacı (2009: 85), makyavelist bakış açısının belirli sınırlar içerisinde tutulmasının örgütler açısından doğru olacağını ve böylelikle makyavelist bireylerin fırsatçı, bencil ve hileci yanlarının örgüte zarar vermesinin engelleneceğini ve hedef odaklılık, başkalarını etkileme gücü gibi olumlu yanlarının korunacağını belirtmişlerdir.

\section{Olumsuz Durumlarn İfş̧ Etme- Makyavelizm İlişkisi}

Literatür incelendiğinde, yapılan araştırmalarda genellikle bireyin etik tavrını ölçek amacıyla Madde Tanımlama Testinin (Defining Issues Test) ve Etik Tavır Anketinin (Ethics Position Questionnaire) kullanıldığ 1 gözlenmiştir. Madde tanımlama ölçeği kullanan çalışmalar ahlaki sorgulamaları yüksek seviyede olan bireylerin, illegal ve ahlaki olmadıklarını düşündükleri olayları daha çok raporlama eğiliminde olduklarını (Arnold ve Ponemon, 1991: 13; Brabeck 1984: 48), diğer taraftan etik tavır anketi kullanan çalışmalarda ise yüksek relativizm düzeyindeki bireylerin daha az, yüksek idealism düzeyindeki bireylerin ise daha çok sorun bildirme eğiliminde olduklarını ifade etmektedir (Chiu ve Erdener, 2003: 350; Barnett ve diğ., 1996: 1170). Bu çalışmada ise ilgili sonuçlar biraz daha ileri taşınmış ve Mach-IV ölçeği (Etik İdeoloji Ölçeği) vasitasıyla Makyavelizm'in olumsuz durumları ifşa etme niyeti üzerindeki etkisi araştırılmıştır.

Literatürde Makyavelizm konusunda yapılan çalışmalarda; muhasebe (Wakefield, 2008: 120 ), iş etiği (Winter ve diğg., 2004: 289) ve sosyal psikoloji (Bańka ve Orlowski, 2012: 219) alanlarında araştırmalara rastlanmaktadır. Niccolo Machiavelli'nin yazılarını yansıtma amaciyla geliştirilen ve bireylerin manipülatif, aldatıcı ve çıkarcı (self-seeking) yönlerini ortaya çıkarmak amacıyla Mach IV kişilik ölçeği geliştirilmiştir (Christie ve Geis, 1970: 73). Bu ölçeğe göre de yüksek makyavelist düzeyde olan bireylerin etik normları ve ahlaki kuralları daha çok ihlal ettikleri öne sürülmektedir. Örneğin, Dahling ve diğerleri (2009) yüksek makyavelistlerin düşük olanlara göre daha çok zarar verici davranışlar sergilediklerini, Tang ve Liu (2012) genelikle bu bireylerin etik olmayan davranışlara meyilli olduklarını, Fehr ve diğerleri (1992) ise bu bireylerin daha çok yalan söyleme, hırsızlık ve aldatma gibi davranışlara yöneldiklerini ifade etmiştir. Ayrıca, diğer bazı çalışmalarda yüksek makyavelist kişilerin kendi ekonomik çıkarlarını maksimize etmek için diğerlerini daha az dikkate aldıkları vurgulanmıştır (Dahling ve di ğ., 2009: 251; Gunnthorsdottir ve diğ., 2002: 62). Bu nedenle bireysel çıkarların, yüksek makyavelist özelliklere sahip bireylerde daha hakim bir düşünce tarzı olduğunu ifade etmek mümkündür.

İlgili literatür kapsamında, bu çalışmada yüksek makyavelist bireylerin düşük olanlara göre daha çok relativist anlaşıya sahip olmaları (Wakefield, 2008: 119) ve etik karar almada genel ahlaki kuralların ötesinde bireysel çıkarlarını daha ön plana almaları nedeniyle, makyavelizm'in olumsuz durumları ifşa etme niyeti ile negatif ilişkili olacağı değerlendirilmektedir. $\mathrm{Bu}$ sebeple çalışma 
kapsamında aşağıda verilen hipotez oluşturulmuştur.

Hipotez: Makyavelizm, olumsuz durumları ifşa etme niyetini negatif yönde etkilemektedir.

\section{Metodoloji}

Çalışma kapsamında öne sürülen hipotezin test edilmesi amaciyla kullanılan veriler, organizasyonlarda tam zamanlı çalışanlardan, yüz-yüze görüşme ile anket uygulaması yapılarak elde edilmiştir. Çalışanlardan; Makyavelizm ve Olumsuz Durumları İfşa Etme Niyetini ölçen değerlendirme formlarını doldurmaları istenmiştir. Çalışmada kullanılan ölçeklerde yer alan ifadelerin Türkçe'ye adaptasyonu için tercüme-tekrar tercüme yöntemi kullanılmıştır (Allen ve Vandenberghe, 2003: 511-515). Bu yöntemde, ölçekteki ifadeler öncelikle araştırmacılar tarafından çevrilmiştir. Daha sonra ölçekteki İngilizce ifadeler literatüre hakim başka bir uzman kişi tarafından da çevrilmiştir. Söz konusu bu iki çeviri tercüman aracılığıyla tekrar ingilizceye çevrilmiştir. Bu sayede ifadelerin doğru bir şekilde dilimize tercüme edilip edilmediği tespit edilmiş ve yapılan geri beslemelerle nihai şekli oluşturulmuştur. Oluşturulan son ölçekler, bu konuda akademik tecrübeye sahip bir öğretim üyesi tarafından içerik yönünden incelendikten sonra veri toplama aşamasına geçilmiştir.

\section{Ortak Yöntem Sapması (Common Method Bias)}

Çalışmada ele alınan verilerin tek kaynaktan toplanması nedeniyle oluşabilecek ortak yöntem hatalarını gidermek için Podsakoff ve diğerleri (2003) tarafından önerilen ve bu tür hataların mimimum seviyelere çekilmesini sağlayan önlemler alınmıştır. Öncelikle, çalışmanın veri toplama aşamasında kullanılan ölçekler, bugüne kadar defalarca kez geçerlilik ve güvenilirliği onaylanmış ölçeklerden seçilmiştir. İkinci olarak da, ilgili örneklem gruba cevapların tamamen gizli tutulacağı ve hiçbir şekilde açıklanmayacağı yüz-yüze yapılan görüşmelerde ifade edilmiştir. Ayrıca, potansiyel sapmaları incelemek için literatürde önemli oranda kabul gören bir teknik olan Harman'ın tek faktör testi kullanılmıştır
(Grafton ve diğg., 2010: 689; Burney ve diğg., 2009: 305). Bu testte bütün değişkenler faktör analizine (principal component) tabi tutulmaktadır. Harman testine göre; önemli düzeyde bir ortak yöntem varyansı (common method variance), tek bir faktörün veya toplam varyansın büyüklüğünü gösteren genel bir faktörün çıkmasıyla anlaşılabilmektedir. Mevcut çalışma kapsamında yapılan faktör analizi sonuçları, özdeğeri 1 'den büyük olan ve toplam varyansların \%69'unu oluşturan 4 faktörü ortaya çıkartmıştır. Birinci faktör toplam varyansın \%27.1'ini oluşturmakta, bu değerde toplam varyansın çoğunluğuna karşılık gelmemektedir. Çıkan sonuçlara göre, bu çalışmadaki ortak yöntem sapmasıyla ilgili bulguların anlamlı düzeyde olmadığını söylemek mümkündür.

\section{Örneklem}

Kayseri'de faaliyet gösteren çeşitli sektörlere ait organizasyonlarda görev alan ve rasgele seçilen 400 kişi ile anket uygulaması yapılmıştır. Eksik ve hatalı kodlamalar ayırt edildikten sonra toplamda 374 anket değerlendirmeye tabi tutulmuştur. Anketler, yüksek bir cevaplanma oranına (Harmon ve diğg., 2002: 53) sahip olup, \%2.6 hata düzeyindedir. Yani, sosyal araştırmalar için aranan $\% 5^{\prime}$ lik seviye aşılmıştır. Katılımcıların çalışma yılı 5 ay ile 39 yıl arasında değişmekte olup ortalama çalışma süresi 10.21 yıldır. Örnek grubunun \%28'i bayanlardan ve \%72'si erkeklerden oluşmaktadır. Katılımcıların yaşları ise 22 ve 56 yaş aralığında değişmekte olup ortalama yaş düzeyi $26.17^{\prime}$ dir. Bu demografik özellikler, işletmelerde etik kapsamında oluşan hataların bildirilmesi için literatürde yapılan diğer çalışmalar çerçevesinde kabul edilebilir seviyeler olarak değerlendirilmektedir (Curtis, 2006: 205; Ayers ve Kaplan, 2005: 124).

\section{Ölçekler}

Makyavelizm düzeyinin ölçümü için Christie ve Geis (1970) tarafından önerilen ve EK-A'da sunulan Mach IV ölçeği kullanılmıştır. Bu ölçek 10 adedi ters kodlamalı olmak üzere 20 ifadeden oluşmaktadır. Makyavelizm düzeyi bu ifadelere verilen cevapların ortalaması olarak ölçülmüştür. Ölçek maddeleri, 1= 
Kesinlikle Katılmıyorum ile $7=$ Kesinlikle Katılıyorum arasında değişen 7'li Likert ölçeğine göre puanlandırılmıştır. Ölçeğin Cronbach's alfa güvenilirlik değeri 0.75; ortalama Makyavelizm düzeyi ise 3.62 olarak tespit edilmiştir.

Olumsuz Durumları Ifş̧a Etme (Whistleblowing) Niyetinin ölçümü için daha önceki whistleblower araştırmalarında kullanılan (Curtis, 2006: 191; Kaplan ve Whitecotton, 2001: 45) ve iki ayrı bağımlı değişken içeren ve olumsuz durumları ifşa etme niyetinin ölçümüne ait bir ölçek kullanılmıştır. Olumsuz durumları ifşa etme niyetini ölçmek için de Schultz ve diğerleri (1993) tarafından ortaya konulan EKB'de sunulan gerçek bir senaryo verilmiştir. Bu senaryonun kullanılmasındaki amaç; organizasyonlarda gerçekleşen yanlış uygulama ve olayların rapor edilme şeklinin ve derecesinin, her bir organizasyonda farklı olabileceği düşüncesidir. Bu sayede, aynı örnek olay referans alınarak, mevcut çalışmadanın örneklem grubunda algılanan etik iklim ve mobbing düzeyine göre, olumsuz durumları ifşa etme niyeti ölçülmüştür. Ölçek maddeleri, $1=$ Kesinlikle Bildirmem ile $7=$ Kesinlikle Bildiririm arasında değişen 7'li Likert ölçeğine göre puanlandırılmıştır. Ölçekte "Yukarıda verilen örnek olaya göre, bu tür bir sorgulanması gereken durumu, bir üst düzey yöneticinize veya yetkili birisine bildirir miydiniz?" sorusu yer almaktadır. Bu tür bir ölçek ile ilk kişinin olumsuz durumları ifşa etme niyeti ölçülmektedir. $\mathrm{Bu}$ bölüm kapsaminda verilen cevapların ortalaması 5.06 olarak gözlenmiştir. Yani, katılımcılar genellikle etik kapsamında yapılan hatalı uygulamaları raporlama eğilimindedir.

Önceki birçok whistle-blower çalışmasında, ilk kişi olumsuz durumları ifşa etme niyeti ölçülmüştür (Liyanarachchi ve Newdick, 2009: 37; MacNab ve Worthley, 2008: 407). Ancak, bazı çalışmalarda ise sosyal beğenilirlik sapmalarının önüne geçebilmek amacıyla, üçüncü kişi perspektifinden olumsuz durumları ifşa etme niyeti ölçülmüştür (Curtis, 2006; 191; Schultz ve diğ., 1993: 99). Ayn amaçla bu çalışmada da, olumsuz durumları ifşa etme niyeti ölçümü için ikinci bağımlı değişken olarak, "Bu organizasyondaki birçok çalışan, yukarıda verilen bir durum karşısındaki olayı rapor eder" şeklinde üçüncü kişi perspektifinden olumsuz durumları ifşa etme niyeti de ölçülmüştür. Bu ölçek için de 1= Kesinlikle Katılmiyorum ile $7=$ Kesinlikle Katılıyorum arasında değişen 7'li Likert ölçeği kullanılmıştır. Cevapların ortalaması 3.81 olarak gözlenmiştir. Bu sonuç, katılımcıların genellikle etik kapsamında yapılan yanlış uygulamaları diğerlerinin raporlama eğiliminde olmadıkları algısına sahip olduklarını göstermektedir.

\section{Araştırma Bulguları}

Çalışmanın tanımlayıcı istatistiklerine ve korelasyonlarına ilişkin değerler Tablo-1'de verilmiştir.

Tablo 1: Değişkenlere Ait Ortalama, Standart Sapma ve Korelasyon Değerleri

\begin{tabular}{|lcccccccc|}
\hline Değişken & Ort & SS & $\mathbf{1}$ & $\mathbf{2}$ & $\mathbf{3}$ & $\mathbf{4}$ & $\mathbf{5}$ & $\mathbf{6}$ \\
\hline 1. Birinci Kişi Niyeti & 5.06 & 1.59 & - & & & & & \\
2. Üçüncü Kişi Niyeti & 3.81 & 1.41 & $0.473^{* * *}$ & - & & & & \\
3. Makyavelizm & 3.62 & 0.61 & $-0.241^{* *}$ & $-0.194^{* *}$ & - & & & \\
4. Yaş & 26.17 & 4.58 & $0.117^{*}$ & 0.087 & 0.072 & - & & \\
5. Cinsiyet & 0.28 & 0.12 & $0.223^{* *}$ & $0.125^{*}$ & $0.109^{*}$ & 0.017 & - & \\
6. Çalışma Süresi & 10.21 & 2.63 & $0.194^{* *}$ & 0.061 & $0.101^{*}$ & $0.142^{*}$ & 0.056 & - \\
\hline
\end{tabular}

Not: Cinsiyet (0=Kadın, $1=$ Erkek); ${ }^{*} \mathrm{p}<0.05 ;{ }^{* *} \mathrm{p}<0.01 ;{ }^{* * *} \mathrm{p}<0.001$; (çift-yönlü) 
Sonuçlar incelendiğinde, cinsiyetle; birinci ve üçüncü kişi olumsuz durumları ifşa etme niyeti arasında anlamlı bir ilişki olduğu görülmektedir. Ayrıca, korelasyon analizi sonuçları, çalışma süresiyle birinci kişi olumsuz durumları ifşa etme niyeti ve makyavelizm arasında zayıf düzeyde de olsa anlamlı ve pozitif yönlü ilişkileri göstermektedir.

Çalışma değişkenlerine ait regresyon analizi sonuçları ise Tablo-2 ve Tablo-3'de sunulmuştur.
Çalışma kapsamında iddia edilen hipotez, makyavelizmin olumsuz durumları ifşa etme niyeti üzerinde negatif yönde bir etkisinin olacağı şeklindedir. Bu hipotezi test etmek için yapılan analiz sonuçlarına göre, makyavelizmin hem birinci kişi hem de üçüncü kişi olumsuz durumları ifşa etme niyeti üzerinde anlamlı ve negatif yönde bir etkisinin olduğunu ifade etmek mümkündür. Yani, makyavelizm düzeyi arttıkça olumsuz durumları ifşa etme niyeti hem birinci kişi hem de üçüncü kişi kapsamında azalmaktadır. Bu sonuçlar çalı̧̧ma kapsamında önerilen hipotezin desteklendiğini göstermektedir.

Tablo 2: Makyavelizm'in Birinci Kişinin Olumsuz Durumları İfşa Etme Niyetine Etkisine Yönelik Regresyon Analizi Sonuçları

\begin{tabular}{|c|c|c|c|c|c|}
\hline \multirow{2}{*}{} & \multicolumn{5}{|c|}{ Bağımlı Değişken: Birinci Kişi Olumsuz Durum İfşa Etme Niyeti } \\
\cline { 2 - 6 } & $\beta$ & $\mathbf{R}^{2}$ & Düzeltilmiş R & $\mathbf{F}$ & Serbestlik \\
Derecesi & & & $11.080^{* *}$ \\
\hline Makyavelizm & -0.241 & 0.098 & 0.097 & 122.771 & \\
\hline
\end{tabular}

Not: Standardize Değerler Kullanılmıştır. ${ }^{* *} \mathrm{p}<0.01$

Tablo 3: Makyavelizm'in Üçüncü Kişinin Olumsuz Durumları İfş̧a Etme Niyetine Etkisine Yönelik Regresyon Analizi Sonuçları

\begin{tabular}{|c|c|c|c|c|c|}
\hline \multirow{2}{*}{} & \multicolumn{6}{|c|}{ Bağımlı Değişken: Üçüncü Kişi Olumsuz Durum İfş̧a Etme Niyeti } \\
\cline { 2 - 6 } & $\beta$ & $\mathbf{R}^{2}$ & Düzeltilmiş R & $\mathbf{F}$ & Serbestlik \\
& & & & 119.671 & $10.839^{* *}$ \\
\hline Makyavelizm & -0.194 & 0.096 & 0.095 & & \\
\hline
\end{tabular}

Not: Standardize Değerler Kullanılmıştır. ${ }^{* *} \mathrm{p}<0.01$ 


\section{Sonuç}

Günümüzde bilgi iletişim teknolojileri ve diğer alanlarda yaşanan değişimler organizasyonlarda hem insan yapısını hem de yönetim tekniklerini etkilemektedir. Özellikle gelişmiş toplumlarda iş ahlakının yönetim uygulamalarında kurumsallaştırılması ve yöneticilerin birer rol model olarak davranışları bilinçli çabaların ürünüdür. $\mathrm{Bu}$ bilinç çerçevesinde de işletmelerde özellikle makyavelist düşüncenin getirdiği ahlaka ve yasalara aykırı davranışların başarılı bir şekilde gözlenmesi ve geri beslemeler yoluyla önlem alınması için olumsuz durumları ifşa etme mekanizmaları geliştirilmiştir.

İşletmelerde özellikle etik merkezli davranışların sergilenmesi ve bu yönde etik bir iklimin oluşturulması makyavelist düşüncelerin azaltılması adına önemli bir unsurdur. Etik iklim, çalışanlara hangi davranışların uygun olduğu ve desteklendiği konusunda da yön vermektedir. İşletmelerde farklı etik iklimlerin oluşmasında kişisel çıkar, şirket karı, faaliyet etkinliği, bireysel arkadaşlıklar, ekiplerin çıkarları ve ilgileri, sosyal sorumluluk, kişisel ahlak, kurallar, standartlar, prosedürler, kanunlar, profesyonel kodlar vb. faktörler çok fazla etkili olmaktadır. Ancak, etik veya yasadışı davranışlara şahit olan çalışanların, örgüt yararını düşünerek bu tür davranışları engellemeye çalışmak amacıyla işletme içi çözüm mercilerine bu sorunu iletmesi, işletmeler açısından uzun dönemde önemli kazançlar sağlamaktadır.

Organizasyonların sürdürülebilir bir başarı ve üstünlük elde etmelerinde önemli bir etken olan bireysel ve örgütsel çıtıların, etik merkezli yönetilmesinin önemi kapsaminda bu çalışmada, makyavelizmin olumsuz durumları ifşa etme niyeti üzerindeki etkisi araştırılmıştır. Araştırmada sorunu tespit edip, bunu yetkililere bildirme düşüncesi olan ilk kişinin olumsuz durumları ifşa etme niyeti ile, sosyal beğenilirlik sapmalarının önüne geçebilmek amaciyla, üçüncü kişi perspektifinden de olumsuz durumları ifşa etme niyetinin ölçümü gerçekleştirilmiştir.

$\mathrm{Bu}$ çalışmada, çeşitli sektörlerde faaliyet gösteren örgütlerin çalışanları ile kurulan senaryolar ve ifadeler üzerine analizler yapılmıştır. Çalışmada, olumsuz durumları ifşa etme niyetinin ölçümü için diğer çalışmalarda olduğu gibi bir senaryo üzerine analizler yapılmıştır (Curtis, 2006: 191; Kaplan ve Whitecotton 2001: 45; Arnold ve Ponemon, 1991: 13). Bu yönde yapilacak diğer çalışmalarda, farklı senaryolarla olumsuz durumları ifşa etme niyetinin araştırılması mümkündür. Ayrıca, çalışmanın diğer bir kısıtı ise çalışma verilerinin diğer olumsuz durumları ifşa etme ve makyavelizm çalışmalarında olduğu gibi (Bloodgood ve diğ., 2010: 23; Street ve Street, 2006: 343; Winter ve diğ., 2004; 289; Kaplan ve Whitecotton, 2001; 45; Schultz ve diğ., 1993: 75) tek bir zamanda toplanmış olmasıdır.

Gelecek araştırmalarda, makyavelizm ve olumsuz durumları ifşa etme ilişkisinde farklı değişkenler (örn. etik iklim algısı, mobbing vs.) kullanılarak araştırma yapılması mümkündür. Bunun yanında, hangi tür etik örgüt çevrelerinin olumsuz durumları ifşa etme niyetini artırdığı yönünde araştırmalarda bulunulması da önemli katkılar sağlayacaktır. Ayrıca, ülkemiz ve kurumlarının gelişmesi ve ilerlemesi kapsamında olumsuz durumları ifşa etme mekanizmasından uzun vadede önemli kazanımlar elde etmek için, bu sürece yönelik gerekli eğitim programlarının oluşturulması, bu tür ihbarda bulunanlar için ödüllendirme sistemlerinin uygulanması ve işletme içi politikalarla bu süreci destekleyici bir düzenleme yoluyla uygun örgüt şartlarının oluşturulmasının uzun dönemde işletmelere önemli katkılar sağlayacağı değerlendirilmektedir. 


\section{Kaynakça}

Ali, Farah, Amorim, Ines Sousa, ve Chamorro-Premuzic, Tomas (2009), Empathy Deficits and Trait Emotional Intelligence in Psychopathy and Machiavellianism, Personality and Individual Differences, 47:7, s.758-762.

Allen, Natalie J. ve Vandenberghe, Cgristian (2003), Examining Organizational Commitment in China, Journal of Vocational Behaviour, 62, s.511515

Appelbaum, Steven H., Iaconi, Giulio David ve Matousek, Albert (2007), Positive and Negative Deviant Workplace Behaviors: Causes, Impacts, and Solutions, Corporate Governance, 7:5, 586-598.

Arnold, Donalt ve Ponemon, L. (1991), Internal Auditors' Perceptions of Whistleblowing and The Influence of Moral Reasoning: An Experiment, Auditing: A Journal of Practice ve Theory, 10:2, s.1-15.

Ateş, Hamza, Bağce, H.Emre ve Şen, Mustafa Lütfi (2009), Tapu Hizmetleri ve Etik, Yolsuzluğun Önlenmesi İçin Etik Projesi, Kamu Etiği Akademik Araştırmaları, 1, s.12-102.

Ayers, Susan, ve Kaplan, Steven E. (2005). Wrongdoing by Consultants: An Examination of Employees' Reporting Intentions, Journal of Business Ethics, 57, s.121-137

Barnett, Tim, Bass, Ken ve Brown, Gene (1996), Religiosity, Ethical Ideology, and Intentions to Report a Peer's Wrongdoing, Journal of Business Ethics, 15, s.1161-1174.

Bańka, Augustyn ve Orłowski, Karol (2012), The Structure of The Teacher Machiavellianism Model in Social Interactions in a School Environment, Polish Psychological Bulletin, 43:4, s.215222.

Bennett, Rebecca ve Stamper, Christina L. (2001), Corporate Citizenship and Deviancy: A Study of Discretionary Work
Behavior, Strategies and Organizations in Transition, 3, s.265-284.

Berkman, Ümit ve Arslan, Mahmut (2009), Dünyada ve Türkiye'de İş Etiği ve Etik Yönetimi, İstanbul: Tüsiad Yayınları.

Biegelman, Martin T. ve Bartow, Joel T. (2006), Executive Roadmap to FraudPrevention and Internal Control, New Jersey: John Wiley ve Sons.

Blenkinsopp, John ve Edwards, Marissa S. (2008), On not Blowing The Whistle: Quiescent Silence as an Emotion Episode, In Emotions, Ethics and Decision-Making, Zerbe, Wilfred J., Hartel, Charmine E. J. ve Ashkanasy, Neal M. (eds.), Bingley: Emerald Group Publishing, s.181-206.

Bloodgood, James M., Turnley, William H. ve Mudrack, Peter E. (2010), Ethics Instruction and The Perceived Acceptability of Cheating, Journal of Business Ethics, 95, s.23-37

Brabeck, Mary (1984), Ethical Characteristics of Whistleblowers, Journal of Research in Personality, 18, s.41-53.

Bucka, Dave ve Kleiner, Brian H. (2001), Whistleblowing in The Aerospace and Defence Industries, Managerial Law,43:1/2, s.50-56.

Burney, Laurie L., Henle, C.hristine A. ve Widener, Sally K. (2009), A Path Model Examining The Relations Among Strategic Performance Measurement System Characteristics, Organizational Justice, and Extra- and in-Role Performance, Accounting, Organizations and Society, 34, s.305-321.

Chiu, Randy K. (2002), Ethical Judgement, Locus of Control, and Whistleblowing Intention: A Case Study of Mainland Chinese MBA Students, Managerial Auditing Journal, 17:9, s.581-587.

Chiu, Randy ve Erdener, Carolyn (2003), The Ethics of Peer Reporting in Chinese Societies: Evidence from Hong Kong and 
Shanghai, International Journal of Human Resource Management, 14:2, s.335-353.

Christie, Richard ve Geis, Florence L. (1970), Studies in Machiavellianism. New York: Academic Press.

Curtis, Mary B. (2006), Are Audit-Related Ethical Decisions Dependent Upon Mood?, Journal of Business Ethics, 68, s.191-209.

Dahling, Jason, Whitaker, Brian G. ve Levy, Paul E. (2009), The Development and Validation of a New Machiavellianism Scale, Journal of Management, 35:2, s.219257.

Fehr, Beverley, Samson, Deborah, ve Paulhus, Delroy L. (1992), The construct of Machiavellianism: Twenty Years Later. In Advances in Personality Assessment, C. Spielberger ve J. Butcher (eds.), Hillsdale, NJ: Lawrence Erlbaum Associates, s.77116.

Gautschi, Frederick H. ve Jones, Thomas M. (1998), Enhancing The Ability of Business Students to Recognize Ethical İssues: An Empirical Assessment of The Effectiveness of A Course in Business Ethics, Journal of Business Ethics, 17:2, s.205-216.

Grafton, Jennifer, Lillis, Anne M. ve Widener, Sally K. (2010), The Role of Performance Measurement and Evaluation in Building Organizational Capabilities and Performance, Accounting, Organizations and Society, 35, s.689-706.

Gunnthorsdottir, Anna, McCabe, Kevin ve Smith, Vernon (2002), Using the Machiavellianism Instrument to Predict Trustworthiness in A Bargaining Game, Journal of Economic Psychology, 23, s.4966.

Harmon, Harry A., Brown, Gene, Widing, Robert E. ve Hammond Kevin L. (2002), Exploring The Sales Manager's Feedback to A Failed Sales Effort, Journal of Business and Industrial Marketing, 17:1, s.43-55.
Hersh, M.A. (2002), Whistleblowers-heroes or Traitors?: Individual and Collective Responsibility for Ethical Behaviour, Annual Reviews in Control, 26, s.243-262.

Jubb, Peter B. (1999), Whistleblowing: A Restrictive Definition and Interpretation, Journal of Business Ethics, 21:1, s.77-94.

Jukiewicz, Carole L., Giacalone, Robert A. ve Knouse, Stephen B. (2004), Transforming Personal Experience into A Pedagogical Tool: Ethical Complaints, Journal of Business Ethics, 53, s.283-295.

Kaplan, Steven ve Whitecotton, Stacey M. (2001), An Examination of Auditors' Reporting Intentions When Another Auditor is Offered Client Employment, Auditing: A Journal of Practice and Theory, 20:1, s.45-63.

Kareshki, Hossein (2011), Relation Among Machiavellianism Belief and Goal Orientations in Academic Situations, Procedia-Social and Behavioral Sciences, 12, s.414-418.

Lacayo, Richard ve Ripley, Amanda (2002), Persons of the Year 2002: The Whistleblowers, Time, Monday, Dec. 30.

Lewis, David ve Uys, Tina (2007), Protection Whistleblower at Work: A Comparison of The Impact of British and South African Legislation, Managerial Law, 3, s.76-92.

Liyanarachchi, Gregory ve Newdick, Chris (2009), The Impact of Moral Reasoning and Retaliation on Whistle-Blowing: New Zealand Evidence, Journal of Business Ethics, 89, s.37-57.

MacNab, Brent R. ve Worthley, Reginald (2008), Self-Efficacy as an Intrapersonal Predictor for Internal Whistleblowing: A US and Canada Examination, Journal of Business Ethics, 79, s.407-421.

Mesmer-Magnus, Jessica R. ve Viswesvaran, Chockalingam (2005), Whistleblowing in Organizations: An Examination of Correlates of Whistleblowing Intentions, Actions, and 
Retaliation, Journal of Business Ethics, 62, s.277-297.

Nam, Dae-il ve Lemak, David J. (2007), The Whistle-Blowing Zone: Applying Barnard's Insights to a Modern Ethical Dilemma, Journal of Management History, 13:1, s.33-42.

O'Connor, Peter J., ve Athota, Vidya S. (2013), The Intervening Role of Agreeableness in The Relationship Between Trait Emotional Intelligence and Machiavellianism: Reassessing The Potential Dark Side Of EI. Personality and Individual Differences, 55, s.750-754.

O'Fallon, Michael J. ve Butterfield, Kenneth D. (2005), A Review of The Empirical Ethical Decision-Making Literature: 1996-2003. Journal of Business Ethics, 59, s.375-413.

Özgener, Şevki, Tanç, Ahmet ve Ulu, Seher (2012), Çalışma Yaşamında Sorun Bildirme Sistemi, Çalışma Yaşamında Davranış: Güncel Yaklaşımlar içinde, Keser, Aşkın, Yılmaz, Gözde ve Yürür, Senay (ed.), Kocaeli: Umuttepe Yayınları.

Paal, Tunde ve Bereczkei, Tamas (2007), Adult Theory of Mind, Cooperation, Machiavellianism: The Effect of Mindreading on Social Relations, Personality and Individual Differences, 4:3, s.541-551.

Park, Heungsik, Rehg, Michael T. ve Lee, Donggi (2005), The Influence of Confucian Ethics and Collectivism on Whistleblowing Intentions: A Study of South Korean Public Employees, Journal of Business Ethics, 58, s.387-403.

Podsakoff, Philip M., MacKenzie, Scott B., Lee, Jeong-Yeon ve Podsakoff. Nathan P. (2003), Common Method Biases in Behavioral Research: A Critical Review of The Literature and Recommended Remedies, Journal of Applied Psychology, 88:5, s.879-903.

Rauthmann, John F. (2012), Towards Multifaceted Machiavellianism: Content,
Factorial, and Construct Validity of a German Machiavellianism Scale, Personality and Individual Differences, 52:3, s.345-351.

Robbins, Stephen P. (1998), Organizational Behavior: Concepts, Controversies, Applications. New Jersey: Prentice Hall Inc.

Robinson, Shani N., Robertson, Jesse C. ve Curtis, Mary B. (2012), The Effects of Contextual and Wrongdoing Attributes on Organizational Employees' Whistleblowing Intentions Following Fraud, Journal of Business Ethics, 106, s.213-227.

Schermerhorn, John R. (1989), Management for Productivity, Third Edition, Carbondale: Southern Illionis John WileyveSons Inc.

Schultz, Joseph J., Johnson, Douglas A., Morris, Deigan ve Dyrnes, Sverre (1993), An Investigation of the Reporting of Questionable Acts in an International Setting, Journal of Accounting Research, 31, s.75-103.

Seifert, Deborah L., Sweeney, John T., Joireman, Jeff ve Thornton, John M. (2010), The Influence of Organizational Justice on Accountant Whistleblowing, Accounting, Organizations and Society, 35, s.707-717.

Sims, Randi L. ve Keenan, John P. (1998), Predictors of External Whistleblowing: Organizational and Intrapersonal Variables. Journal of Business Ethics, 17, s.411-422.

Street, Marc ve Street, Vera L. (2006), The Effects of Escalating Commitment on Ethical Decision-Making, Journal of Business Ethics, 64, s.343-356.

Tang, Thomas Li-Ping ve Liu, Hsi (2012), Love of Money and Unethical Behavior Intention: Does an Authentic Supervisor's Personal Integrity and Character (ASPIRE) Make a Difference?, Journal of Business Ethics, 107, s.295-312. 
Tavakoli, A., Keenan, John P. ve CrnjakKaranovic, B. (2003), Culture and Whistleblowing: An Empirical Study of Croatian and United States Managers Utilizing Hofstede's Cultural Dimensions, Journal of Business Ethics, 43, s.49-64.

Taylor, Eileen Z. ve Curtis, Mary B. (2010), An Examination of The Layers of Workplace Influences in Ethical Judgments: Whistleblowing Likelihood and Perseverance in Public Accounting, Journal of Business Ethics, 93, s.21-37.

Teven, Jason J. (2007), Teacher Machiavellianism and Social Influence in the College Classroom: Implications for Measurement, Communication Research Reports, 24:4, s.341-352.

Wakefield, Robin (2008), Accounting and Machiavellianism, Behavioral Research in Accounting, 20, s.115-129.

Winter, S., Stylianou, A., ve Giacalone, R. (2004), Individual Differences in the Acceptability of Unethical Information Technology Practices: The Case of Machiavellianism and Ethical Ideology, Journal of Business Ethics, 54, s.279-301. 


\section{EK-A: Makyavelizm Ölçeği}

Aşağıda verilen ifadelere katılma derecenizi belirtiniz.

Kesinlikle

Katılmiyorum

(1)
(2)

(3)

\section{Ne Katıliyorum}

Ne Katılmiyorum
Kesinlikle

Katılıyorum

(4)

(5)
(7)

\section{Iffadeler:}

1. İnsanları kontrol altında tutmak için onlara duymak istedikleri şeyleri söylemek en iyi yoldur (......)

2. İnsanlardan sizin için bir şey yapmasını istediğinizde, boştan gerekçeler sunmak yerine gerçek gerekçenin ne olduğunu söylemeniz daha iyidir (......)

3. Başka birisine tamamen güvenen bir kişi başına bela aramaktadır (......)

4. İşin kolayına kaçmadan bir şeyler elde etmek çok zordur (......)

5. Dürüstlük her durumda en iyi çözümdür (......)

6. Tedbirli olan yol, insanların fırsat yakaladığında ahlaksız yönlerinin ortaya çıkacağını farz etmektir (......)

7. Gerçek sorunları, kendine fayda getirmeyeceğine inanıyorsan kesinlikle kimseye söyleme (......)

8. Bir kişi herhangi bir olayı ahlaki olarak doğru buluyorsa, o olaya yönelik gerekli adımları atmalıdır (......)

9. Önemli insanlara yağcılık yapmak akıllıca olandır (......)

10. Alçakgönüllü ve dürüst olmak, her şeyin ötesinde, ahlaksız olmaktan daha iyidir (......)

11. Dünya'da her dakika bir enayinin (veya kerizin) doğduğu düşüncesi yanlıştır (......)

12. Çaresiz hastalıklara maruz kalan kişiler, acımasız bir şekilde ölüme gitme yolunu seçme hakkına sahip olmalıdır (......)

13. Bütün durumlarda saygıdeğer olmak iyi bir şeydir (......)

14. Bütün insanlar temelinde iyi ve naziktir (......)

15. Başkasına yalan söylemenin hiçbir özrü yoktur (......)

16. Birçok insan babasının ölümünü, varlığını kaybetmekten daha önce unutmaktadır (.......)

17. Bu dünyanın daha sade ve yalın bir hale kavuşmasında ahlaki yaşama sahip olanlar önemli bir yere sahiptir (......)

18. Genel olarak ifade etmek gerekirse, erkekler bir zorlama olmadıkça çalışmayacaktır (......)

19. Birçok suçlu ile diğer insanlar arasındaki en büyük farklılık, suçluların yakalanacak kadar aptal olmasıdır (......)

20. Birçok insan cesurdur (......)

Not: Verilen ifadelerden 2, 5, 8, 10, 11, 13, 14, 15, 17, 20 ters yönlüdür. 


\section{EK-B: Olumsuz Durumları İfşa Etme Niyeti (Whistleblowing) Senaryosu}

Nathan Mikelsen yaklaşık iki yıldır bir imalat merkezinde satın alma şefi olarak görev yapmaktadır. Nathan bir gün altında çalışan ve Largo firmasından büyük miktarlarda alım yapan personeli olan Tim Clevelend'in konuşmalarına istemeden kulak misafiri olur. Konuşma esnasında, Clevelend Largo firmasının av köşkünü 1 haftalığına kullanmak istediğini söyler. Daha sonra Nathan Clevelend'i çağırarak Largo firmasının verdiği fiyat teklifini diğer tedarikçilere göre biraz yüksek bulduğunu belirtir. Ancak, Cleveland ise Largo firmasından uzun dönemdir tedarikte bulunduklarını ve kendi firmasıyla bu firma arasında güzel ilişkiler kurulduğunu ve ayrıca Nathanın da bu firma ile ilişkiler geliştirmesinin kendisine fayda sağlayacağını dile getirir. Ancak, Nathan tedarikçilerden herhangi bir hediye almasının firma politikalarına aykırı olduğunu bilmektedir. Böyle bir durumda Nathan ne yapmalıdir?

\section{Kesinlikle}

\section{Bildirmem}

(1)

(2)

\section{Ne Bildiririm \\ Ne Bildirmem}

(4)

\section{Kesinlikle}

Bildiririm

Yukarıda verilen örnek olaya göre, bu tür bir sorgulanması gereken durumu bir üst düzey yöneticinize veya yetkili birisine bildirir miydiniz? (......)

\section{Kesinlikle}

Katılmiyorum

(1)
(2)
Ne Katılıyorum

Ne Katılmiyorum

(4)
(5)
(6)
(7)

Bu organizasyondaki birçok çalışan, yukarıda verilen örnek olaya benzer bir sorgulanması gereken durumu bir üst düzey yöneticisine veya yetkili birisine rapor eder (......) 